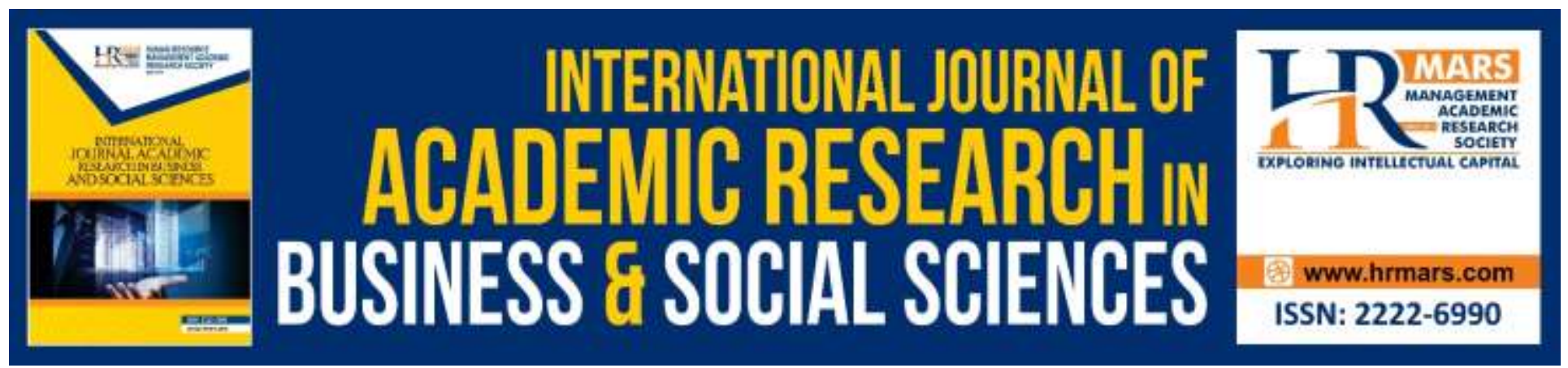

\title{
Construct Validity and Reliability of Human Capital Self- Assessment Questionnaires Instrument
}

Nor Haslan Nor Zaman, Mohammad Shatar Sabran \& Ahmad Hashim

To Link this Article: http://dx.doi.org/10.6007/IJARBSS/v10-i6/7285

DOI:10.6007/IJARBSS/v10-i6/7285

Received: 10 April 2020, Revised: 12 May 2020, Accepted: 09 June 2020

Published Online: 17 June 2020

In-Text Citation: (Zaman et al., 2020)

To Cite this Article: Zaman, N. H. N., Sabran, M. S., \& Hashim, A. (2020). Construct Validity and Reliability of Human Capital Self-Assessment Questionnaires Instrument. International Journal of Academic Research in Business and Social Sciences, 10(6), 257-267.

Copyright: @ 2020 The Author(s)

Published by Human Resource Management Academic Research Society (www.hrmars.com)

This article is published under the Creative Commons Attribution (CC BY 4.0) license. Anyone may reproduce, distribute, translate and create derivative works of this article (for both commercial and non-commercial purposes), subject to full attribution to the original publication and authors. The full terms of this license may be seen

at: http://creativecommons.org/licences/by/4.0/legalcode

\section{Vol. 10, No. 6, 2020, Pg. $257-267$}

http://hrmars.com/index.php/pages/detail/IJARBSS

JOURNAL HOMEPAGE

Full Terms \& Conditions of access and use can be found at http://hrmars.com/index.php/pages/detail/publication-ethics 


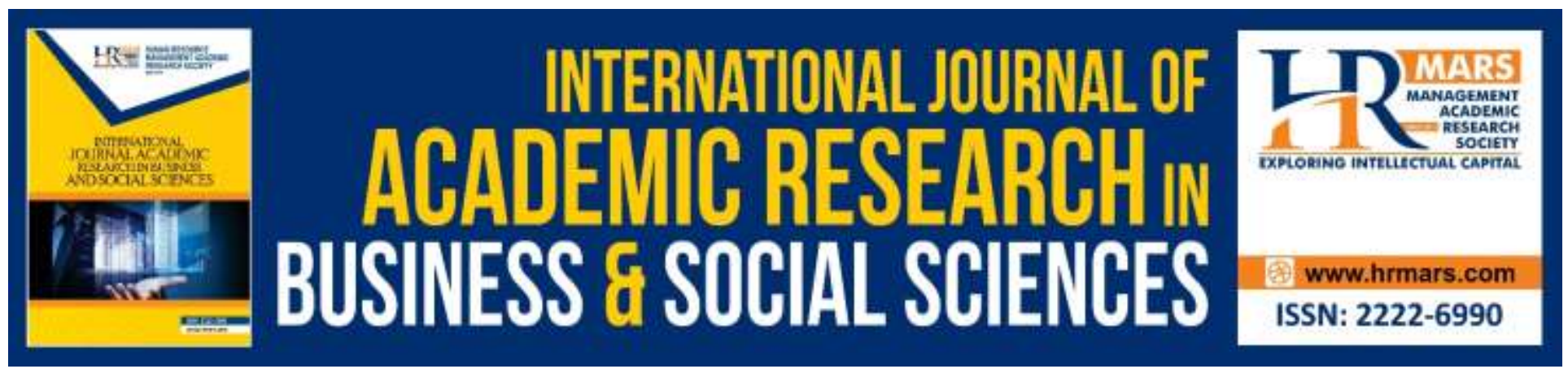

\title{
Construct Validity and Reliability of Human Capital Self-Assessment Questionnaires Instrument
}

\section{Nor Haslan Nor Zaman, Mohammad Shatar Sabran \& Ahmad Hashim}

Universiti Pendidikan Sultan Idris, Tanjong Malim, Perak

Email: has_reen98@yahoo.com

\begin{abstract}
This study was conducted to obtain the construct validity and reliability of Human Capital SelfAssessment questionnaires instrument among thirteen years old male and female students in Perak, Malaysia. Eighty students from the secondary schools in Kinta Utara and Perak Tengah districts were involved in this study. 100 questionnaire items were built that represent six constructs that are knowledge, thinking skills, leadership skills, bi-languange skills, ethics and spirituality, and national identity aspirations. Factor analysis showed only 83 items that's represented the six constructs were accepted. The Cronbach-Alpha showed reliability coefficient for all constructs were between $\alpha=.73$ to $\alpha=.92$ with the total Cronbach-Alpha value of $\alpha=89$.thus, findings showed that the Human Capital Self-Assessment questionnaires instrument have validity and realibility among the studied population.
\end{abstract}

Keywords: Knowledge Aspiration, Thinking Skills Aspiration, Leadership Skills, Bi-Language Skills Aspiration, Ethics and Spiritual Aspirations, National Identity Aspiration.

\section{Introduction}

Education in Malaysia is not only aimed at developing the country's social and economic capital, but also as a catalyst for creativity and innovation for the younger generation (Nordin, 2017). The educational transformation outlined in the Malaysian Education Development Plan 2013-2025 aims not only to develop students' aspirations in terms of knowledge and skills, but also the development of critical thinking, creative and innovative thinking skills, leadership skills, skills in Bahasa Malaysia and English language (bilingual skills), the character and values, and spirit of strong national identity through co-curricular activities need to be emphasized and emphasized. This is because quality human capital is the most important element in achieving the objectives of the Education Development Plan 2013-2025.

According to a study by Zakaria, Nasroddin and Hashim (Zakaria, Nasroddin, \& Hashim, 2015) pointed out that some countries can achieve high economic growth through quality human capital despite physical limitations. This, in turn, supports the idea that elements of human capital evolution are important in generating knowledgeable and highly morale individuals. Therefore, the agenda of 
INTERNATIONAL JOURNAL OF ACADEMIC RESEARCH IN BUSINESS AND SOCIAL SCIENCES Vol. 10, No. 6, June, 2020, E-ISSN: 2222-6990 @ 2020 HRMARS

human capital development should be nurtured through the involvement of students in co-curricular activities in schools. Additionally, human capital development is a priority for a country's development process as it is a catalyst that will shape the nation's progress and decline.

The curriculum offers a wealth of knowledge, experience, skills and training, based on integrated and holistic concepts of education and human development that can produce positive effects in establishing high aspirations in education and reducing dropout problems (Samad \& Idris, 2017). According to Baharom and Idris (Baharom \& Idris, 2017), co-curricular activities are considered to be a very effective activity to foster students' balanced mental, spiritual, social and social development. Through the involvement of students in various co-curricular activities, aspects of the skills can be applied and instilled in the students whether they are aware of it or not. The statement was also supported by Ashfaq, Aslam and Hussain (Ashfaq, Aslam, \& Hussain, 2017) who argued that the application of these aspects of skills in co-curricular activities can foster healthy lifestyles and generate good student self-image as well as apply spiritual education, leadership, teamwork (Buhari, 2015; Yusak, bin Abdul Rahim, \& Ramli, 2019) and self-confidence. Through co-curricular activities, students are able to increase their self-confidence, increase their knowledge and gain experience in solving problems. This mastery gives students the opportunity to move on with their lives and realize Malaysia's hope of becoming a developed nation compared to other developed countries (Mohd Shariff, Javed, \& Md Nadzalan, 2019; Rahmat, Shahril, Salimin, Ahmad, \& Nadzalan, 2017; Rani, Yusof, Kamarulzaman, \& Omar, 2016).

Mancha and Ahmad (Mancha \& Ahmad, 2016) and Baharom and Idris (Baharom \& Idris, 2017) also emphasize that co-curricular activities in schools can build communication skills and help to shape students positively (Yaakob, Yunus, \& Jafar, 2020) which in turn will help them a lot in their future career paths. Students can prepare themselves for the complex demands of the job market through experience of activities gained through the co-curricular activities provided by the school (Adnan \& Warman, 2017). Based on these interests, it is appropriate for students to take the initiative to develop themselves by cultivating awareness as well as striving to master various other skills through co-curricular activities provided by the schools for the purpose of expanding student knowledge and mastery in enhancing the skills and be competent in responding to the challenges of globalization. The development of human capital needs to be promoted productively and the educational process through co-curricular activities becomes a turning point in the endeavor.

According to Yunus and Ahmad (Yunus \& Ahmad, 2016), the role of schools should be to provide students with a wide range of skills and to meet the standards of the industry. The skills students have will help them compete at the next level. According to Sidik, Awang and Ahmad (Sidik, Awang, \& Ahmad, 2018), schools should always be able to produce holistic human capital and be able to compete internationally. The Ministry of Education's ambition through the Malaysian Education Development Plan 2013-2025 which emphasizes on the aspect of student-centered education has been aimed at strengthening student incarceration as outlined in the National Philosophy of Education. Sidik et al. (Sidik et al., 2018) also pointed out that all parties should provide support and opportunities for students to participate in various co-curricular activities in schools to create a balanced human capital within the students. Without the cooperation of all parties, especially the students themselves, the application of a balanced human capital to the students as long as they are in school cannot be achieved. Therefore, its implementation should take into account several factors of the school environment that influence student involvement in co-curricular activities at the school. 
Student achievement in the context of this study will be evaluated using a self-assessment tool developed by the researcher. The evaluation of human capital in co-curricular activities conducted in schools is necessary as it strengthens the national education system. This was in line with Al-Ansari et al. (Al-Ansari et al., 2016) statement that in addition to the influence of students' background and academic status, involvement in co-curricular activities is also influenced by students' perceptions of their activities. With this assessment, we can see how effective the cocurricular activities are in each school and the mission of the Malaysian Education Development Plan 2013-2025 that has been implemented and realized.

According to Al-Tabany (Al-Tabany, 2017) and Setiadi (Setiadi,2016), assessment is an important component of the learning and teaching process. The findings of evaluation and assessment can inform educators about the effectiveness of the approach, strategy or technique in the co-curricular activities used. For a student, it is an indicator of what they have learned, what is still to be learned, and how to best learn something from the co-curricular activities. Therefore, selfassessment can be defined as students evaluating their own work based on clear evidence and criteria for the purpose of improving their future performance (Prihamdani, 2016). Engaging students in their own assessment can add reflection and metacognition to the learning process. Based on this statement, assessment instruments can be developed to students for the purpose of assessing their involvement in co-curricular activities related to human capital development. The objectives of this study are to;

- determine the validity of the human capital self-assessment instrument items among 13 years old based on co-curricular activities,

- determine the reliability of human capital self-assessment instruments among 13-years old students following co-curricular activities.

\section{Methodology}

This study used a pre-experimental design of the One Group Pre Test-Post-Test and a correlation method using a self-administered questionnaire. This study is divided into three phases. The first phase begins with the construction of a human capital self-assessment questionnaire and content validation through language experts and field experts. The second phase is the reliability of the questionnaire items. The third phase involves measuring item validity using factor analysis.

\section{Sampling}

In this study, researchers used a sample size of 160 students consisting of male $(n=90)$ and female students $(n=70)$ aged 13 to determine the construct validity of questionnaire items. To determine the reliability of the instrument, 80 different student samples consisting of male $(n=40)$ and $13(n=$ 40) female students were selected from both schools. All randomly selected samples were from only two schools taking into account all races involved in the study.

\section{Variables}

In this study the dependent variables were 13 year old boys and girls while the independent variables were knowledge aspiration scores, thinking skills aspiration scores, leadership skills aspiration scores, 
INTERNATIONAL JOURNAL OF ACADEMIC RESEARCH IN BUSINESS AND SOCIAL SCIENCES

Vol. 10, No. 6, June, 2020, E-ISSN: 2222-6990 @ 2020 HRMARS

bilingual skills aspiration scores, spiritual ethical aspirations scores and national identity aspiration scores.

\section{Instrument}

Researchers developed human capital assessment instruments based on the Buku Panduan Pengurusan Kokurikulum (Bahagian Sukan, 2009), Panduan Pengurusan Kokurikulum di Sekolah (Ramlan, 2004) and the Malaysian Education Development Plan 2013-2025 (Malaysia, 2013). Researchers used the five-point Likert Scale to test human capital based on knowledge aspirations, thinking skills, leadership skills, bilingual, ethical and spiritual, and national identities. There are five scales in which; scale 1: strongly disagree, scale 2: disagree, scale 3: uncertain, scale 4: agree, scale 5: strongly agree.

\section{Data Analysis}

The Statistical Package for Social Science version 20 program was used to analyze data collected based on human capital self-assessment instruments. Pearson correlation analysis was used to obtain validity scores based on linguists and field experts. Statistical analysis of the Cronbach-Alpha coefficient method was used to determine the reliability level of the internal consistency of the human capital self-assessment instrument. Furthermore, to determine the construct validity of a human capital self-assessment instrument among 13-year-old students, researchers used factor analysis.

\section{Results}

Findings showed that the validity of language experts based on the 5 items of the scale from 1 to 5 using the formula proposed by Mohd and Ahmad (Mohd \& Ahmad, 2005) is $r=.92$. Whereas the validity of field experts based on 11 items of questionnaire on the scale of 1 to 5 using the formula proposed by Mohd and Ahmad (Mohd \& Ahmad, 2005) was $r=.87$. A total of 100 items in the human capital self-assessment questionnaire were constructed based on six factors. These factors are knowledge aspirations, thinking skills aspirations, leadership skills aspirations, bilingual skills appraisals, spiritual and ethical aspirations, and national identity aspirations. Based on factor analysis, only 83 items showed a factor loadings of \pm 0.4 and were used for this study. Statistical analysis of the Cronbach's-Alpha coefficient method was used to determine the reliability level of the internal consistency of the human capital self-assessment instrument. The overall alpha coefficient of Cronbach's alpha for each factor in the human capital self-assessment instrument was $\alpha=.98$. Reliability values of knowledge aspiration ( $\alpha=.93$ ), thinking skills aspiration $(\alpha=.92)$, leadership skills aspirations ( $\alpha=.92)$, bilingual skills appraisal $(\alpha=.94)$, spiritual ethical aspirations $(\alpha=.81)$ and national identity aspirations $(\alpha=.73)$ were accepted and used in this study.

The factor analysis results in table 1 below show that most items of the human capital selfassessment instrument based on correlation coefficient values are 0.3 and above. The Kaiser-Meyer Olkin (KMO) value is .87 more than the .50 value suggested by Chua (Chua, 2014). The Bartlett's Test of Sphericity was significant $(p=.001)$. Therefore, the factor analysis technique is suitable for subsequent testing. 
INTERNATIONAL JOURNAL OF ACADEMIC RESEARCH IN BUSINESS AND SOCIAL SCIENCES

Vol. 10, No. 6, June, 2020, E-ISSN: 2222-6990 @ 2020 HRMARS

Table 1 - Bartlett's Test of Sphericity and Kaiser-Meyer-Olkin (KMO)

\begin{tabular}{llr}
\hline Kaiser-Meyer-Olkin Measure of Sampling Adequacy & .869 \\
\hline Bartlett's Test of Sphericity & Approx. Chi-Square & 12856.695 \\
& df & 4950 \\
& Sig. & .001
\end{tabular}

The Kaiser's criterion technique is used to determine the number of components. Only components with eigenvalue 1 or more were selected in this analysis. According to table 2 below there are 24 components with more than 1 eigenvalue $(36,812,3.023,2.595,2.456,2.364,2.122$, 2.024, 1.888, 1.823, 1.724, 1,652, 1.615, 1.527, 1.448, 1.406, 1.325, 1.311, 1,200, 1.152, 1.144, 1.140, $1.088,1.041,1.024)$. All 24 of these components account for 74.902 percent of the variance.

Table 2 - Variances

\begin{tabular}{lcccccc}
\hline \multirow{2}{*}{$\mathrm{t}$} & \multicolumn{5}{c}{ Initial Eigenvalues } & \multicolumn{3}{c}{ Extraction Sums of Squared Loadings } \\
\cline { 2 - 6 } & Total & $\begin{array}{c}\text { \% of } \\
\text { Variance }\end{array}$ & $\begin{array}{c}\text { Cumulative } \\
\%\end{array}$ & Total & $\begin{array}{c}\text { \% of } \\
\text { Variance }\end{array}$ & $\begin{array}{c}\text { Cumulative } \\
\%\end{array}$ \\
\hline 1 & 36.812 & 36.812 & 36.812 & 36.812 & 36.812 & 36.812 \\
2 & 3.023 & 3.023 & 39.834 & 3.023 & 3.023 & 39.834 \\
3 & 2.595 & 2.595 & 42.429 & 2.595 & 2.595 & 42.429 \\
4 & 2.456 & 2.456 & 44.885 & 2.456 & 2.456 & 44.885 \\
5 & 2.364 & 2.364 & 47.249 & 2.364 & 2.364 & 47.249 \\
6 & 2.122 & 2.122 & 49.371 & 2.122 & 2.122 & 49.371 \\
7 & 2.024 & 2.024 & 51.394 & 2.024 & 2.024 & 51.394 \\
8 & 1.888 & 1.888 & 53.282 & 1.888 & 1.888 & 53.282 \\
9 & 1.823 & 1.823 & 55.105 & 1.823 & 1.823 & 55.105 \\
10 & 1.724 & 1.724 & 56.829 & 1.724 & 1.724 & 56.829 \\
11 & 1.652 & 1.652 & 58.481 & 1.652 & 1.652 & 58.481 \\
12 & 1.615 & 1.615 & 60.097 & 1.615 & 1.615 & 60.097 \\
13 & 1.527 & 1.527 & 61.623 & 1.527 & 1.527 & 61.623 \\
14 & 1.448 & 1.448 & 63.072 & 1.448 & 1.448 & 63.072 \\
15 & 1.406 & 1.406 & 64.477 & 1.406 & 1.406 & 64.477 \\
16 & 1.325 & 1.325 & 65.802 & 1.325 & 1.325 & 65.802 \\
17 & 1.311 & 1.311 & 67.114 & 1.311 & 1.311 & 67.114 \\
18 & 1.200 & 1.200 & 68.314 & 1.200 & 1.200 & 68.314 \\
19 & 1.152 & 1.152 & 69.465 & 1.152 & 1.152 & 69.465 \\
20 & 1.144 & 1.144 & 70.609 & 1.144 & 1.144 & 70.609 \\
21 & 1.140 & 1.140 & 71.749 & 1.140 & 1.140 & 71.749 \\
22 & 1.088 & 1.088 & 72.836 & 1.088 & 1.088 & 72.836 \\
23 & 1.041 & 1.041 & 73.878 & 1.041 & 1.041 & 73.878 \\
24 & 1.024 & 1.024 & 74.902 & 1.024 & 1.024 & 74.902 \\
\hline$E x t r a c t i o n y y y$ & & & & & &
\end{tabular}

Extraction Method: Principal Component Analysis

To retain all three components for the purpose of further analysis, the researchers used the varimax rotation method to minimize the number of high-correlated questionnaire items per factor. According to Tabachnick, Fidell and Ullman (Tabachnick, Fidell, \& Ullman, 2007), results based on 
INTERNATIONAL JOURNAL OF ACADEMIC RESEARCH IN BUSINESS AND SOCIAL SCIENCES

Vol. 10, No. 6, June, 2020, E-ISSN: 2222-6990 @ 2020 HRMARS

orthogonal rotation are easier to interpret and report. Table 3 below shows the results of three rotation components using the varimax rotation method. The results showed that component one explained 10.966 percent variant, component two 9.767 percent variant, component three 9.694 percent variant, component four 9.414 percent variant, component five 5.656 percent variant, component six 3.873 percent variant. The total variance explained by the six components was 49.371 percent.

Table 3 - Variances

\begin{tabular}{cccc}
\hline \multirow{2}{*}{ Component } & \multicolumn{3}{c}{ Rotation Sums of Squared Loadings } \\
\cline { 2 - 4 } & Total & \% of Variance & Cumulative \% \\
\hline 1 & 10.966 & 10.966 & 10.966 \\
2 & 9.767 & 9.767 & 20.733 \\
3 & 9.694 & 9.694 & 30.427 \\
4 & 9.414 & 9.414 & 39.841 \\
5 & 5.656 & 5.656 & 45.497 \\
6 & 3.873 & 3.873 & 49.371 \\
\hline
\end{tabular}

Extraction Method: Principal Component Analysis

Table 4 showed a loading factor of more than $r=.40$ for the six components of the human capital self-assessment survey instrument. The high correlation coefficient values of the test results on the measured factors indicate a close relationship with the factors (Tabachnick et al., 2007). According to Principal Component Analysis, only 83 items showed a high score out of a total of 100 questionnaire items. According to McCrae and Terracciano (McCrae \& Terracciano, 2005) based on a factor loadings of more than 0.40 , only 83 questionnaires were considered valid to be accepted as items in the human capital self-assessment instrument in this study.

Table 4 - Construct validity in Ideas for Matrix Rotation Components

\begin{tabular}{|c|c|c|c|c|c|c|}
\hline & \multicolumn{6}{|c|}{ Component } \\
\hline & 1 & 2 & 3 & 4 & 5 & 6 \\
\hline s41 & .654 & & & & & \\
\hline s57 & .614 & & & & & \\
\hline s21 & .612 & & & & & \\
\hline$s 62$ & .599 & & & & & \\
\hline s55 & .598 & & & & & \\
\hline s43 & .596 & & & & & \\
\hline s11 & .570 & & & & & \\
\hline s29 & .553 & & & & & \\
\hline s22 & .522 & & & & & \\
\hline s35 & .512 & & & & & \\
\hline s34 & .502 & & & & & \\
\hline s97 & .494 & & & & & \\
\hline s49 & .484 & & & & & \\
\hline s45 & .476 & & & & & \\
\hline s13 & .475 & & & & & \\
\hline
\end{tabular}


INTERNATIONAL JOURNAL OF ACADEMIC RESEARCH IN BUSINESS AND SOCIAL SCIENCES Vol. 10, No. 6, June, 2020, E-ISSN: 2222-6990 @ 2020 HRMARS

\begin{tabular}{|c|c|c|c|c|}
\hline s56 & .457 & & & \\
\hline s98 & .456 & & & \\
\hline s69 & .456 & & & \\
\hline s37 & .445 & & & \\
\hline s5 & .444 & & & \\
\hline s92 & .433 & & & \\
\hline s77 & -.421 & & & \\
\hline s80 & .415 & & & \\
\hline s16 & & .629 & & \\
\hline s17 & & .589 & & \\
\hline s86 & & .552 & & \\
\hline s4 & & .550 & & \\
\hline s30 & & .539 & & \\
\hline s65 & . & .532 & & \\
\hline s87 & & .516 & & \\
\hline s61 & & .506 & & \\
\hline s27 & & .505 & & \\
\hline s66 & & .483 & & \\
\hline s88 & & .465 & & \\
\hline$s 60$ & & .453 & & \\
\hline s46 & & .430 & & \\
\hline s7 & & .430 & & \\
\hline s54 & & .406 & & \\
\hline s100 & & & .655 & \\
\hline s89 & & & .625 & \\
\hline s73 & & & .590 & \\
\hline s85 & & & .562 & \\
\hline s93 & & & .520 & \\
\hline s96 & & & .518 & \\
\hline s58 & & & .517 & \\
\hline s83 & & & .514 & \\
\hline s95 & & & .511 & \\
\hline s91 & & & .496 & \\
\hline s48 & & & .444 & \\
\hline s75 & & & .436 & \\
\hline s94 & & & .425 & \\
\hline s20 & & & .419 & \\
\hline s59 & & & & .716 \\
\hline s63 & & & & .501 \\
\hline s24 & & & & .500 \\
\hline s78 & & & & .499 \\
\hline s44 & & & & .489 \\
\hline s81 & & & & .486 \\
\hline s52 & & & & .483 \\
\hline
\end{tabular}


INTERNATIONAL JOURNAL OF ACADEMIC RESEARCH IN BUSINESS AND SOCIAL SCIENCES

Vol. 10, No. 6, June, 2020, E-ISSN: 2222-6990 @ 2020 HRMARS

\begin{tabular}{lll} 
s74 & .473 & \\
s25 & .470 & \\
s53 & .457 & \\
s19 & .449 & \\
s72 & .439 & \\
s33 & .426 & \\
s9 & .425 & \\
s79 & .422 & \\
s42 & .417 & \\
s68 & .415 & \\
s47 & .411 & \\
s36 & & .637 \\
s64 & & .510 \\
s3 & & .509 \\
s38 & & .500 \\
s10 & & .500 \\
s31 & & .469 \\
s23 & & \\
s40 & & \\
s50 & & .458 \\
s28 & & \\
s26 & & \\
s1 & & \\
s71 & & .408 \\
\hline & & \\
\end{tabular}

Extraction Method: Principal Component Analysis.

Rotation Method: Varimax with Kaiser Normalization.

\section{Discussion}

Factor analysis is the most appropriate statistical analysis to obtain the construct validity of the human capital self-assessment instrument. According to Pallant (Pallant, 2013), the goal of factor analysis is to reduce the number of variables associated with easier numbers to manage. Factor analysis was performed following three main steps; First, the assessment of data suitability for factor analysis, second, factor extraction and lastly, factor rotation and interpretation (Pallant \& Manual, 2010). Out of 100 questionnaire items, a total of 83 items were found to have high validity and reliability in measuring human capital among 13-year-old boys and girls in Perak.

\section{Conclusion}

This study has been able to develop human capital self-assessment instruments to identify human capital among students. The results of this study indicate that six factors (knowledge aspirations, thinking skills aspirations, leadership skills aspirations, bilingual skills aspirations, spiritual ethical aspirations, and national identity aspirations) are valid and reliable for assessing student human capital through co-curricular activities. In line with this study, the conceptual and theoretical framework used is a combination of three theories, namely the theory or Model of the Human Ecological System (Bronfenbrenner, 1977), which is the main theory and supported by Social 
INTERNATIONAL JOURNAL OF ACADEMIC RESEARCH IN BUSINESS AND SOCIAL SCIENCES Vol. 10, No. 6, June, 2020, E-ISSN: 2222-6990 @ 2020 HRMARS

Capital Theory (Putnam, 2000) to see how climate and school culture impact on student bullying and the theory of Multiple Intelligence Theory founded by Gardner (2011) explaining that various intelligence factors have their own purpose in contributing to the development of quality human capital through student involvement in co-curricular activities in school. The implications of this study are to provide effective feedback on the performance of human capital to the school so that teachers and school administrators can identify student weaknesses in the implementation of cocurricular activities based on the use of valid and reliable human capital assessment instruments and take corrective measures. Findings using this instrument can also serve as a standard indicator of useful norms for co-curricular teachers, school administrators, the District Education Office, the State Education Department, and the Ministry of Education Malaysia to design appropriate interventions to assess the impact of school curriculum activities on on the human capital of the students. Further studies need to be expanded to look at many other environmental influences such as academic achievement, peer pressure behavior, depression, teacher and community influences that impact student engagement in co-curricular activities.

\section{References}

Samad, A. N., \& Idris, M. S. (2017). Co-curricular importance in Secondary School. Educational Technology, 47747-47751.

Adnan, W. N., \& Warman, S. (2017). Extra-curricular activities affect students to develop social skills. Leadership Management, 46034-46036.

Al-Ansari, A., Al-Harbi, F., AbdelAziz, W., AbdelSalam, M., El Tantawi, M. M., \& ElRefae, I. (2016). Factors affecting student participation in extra-curricular activities: A comparison between two Middle Eastern dental schools. The Saudi dental journal, 28(1), 36-43.

Al-Tabany, T. I. B. (2017). Mendesain Model Pembelajaran Inovatif, Progresif, Dan Konteksual: Prenada Media.

Ashfaq, M., Aslam, S., \& Hussain, S. A. (2017). The impact of co-curricular activities on the overall performance of secondary school students in Fata. Tolerant attitude and managerial conduct among professionals of Physical Education and Sports 01, 33.

Sukan, B. S. D. K. B., Kementerian Pendidikan Malaysia. (2009). Buku Panduan Pengurusan Kokurikulum. Kuala Lumpur: A.G Grafik, Sdn. Bhd.

Baharom, N., \& Idris, M. S. (2017). The roles of co-curricular in promoting students human capital development. Educational Technology, 47664-47666.

Bronfenbrenner, U. (1977). Toward an experimental ecology of human development. American psychologist, 32(7), 513.

Buhari, A. (2015). Pembangunan kemahiran kerja berpasukan menerusi kokurikulum sukan hoki dalam kalangan pelajar UTHM. Universiti Tun Hussein Onn Malaysia.

Chua, Y. (2014). Asas Statistik Penyelidikan Buku 3: Analisis Data Skala Ordinal dan Skala Nominal. Shah Alam: McGraw-Hill Education.

Gardner, H. (2011). Frames of mind: The theory of multiple intelligences: Hachette Uk.

Malaysia, K. P. (2013). Pelan Pembangunan Pendidikan Malaysia 2013-2025. Putrajaya.

Mancha, S., \& Ahmad, A. (2016). Co-curricular activities and its effect on social skills. Paper presented at the International conference on education and regional development.

McCrae, R. R., \& Terracciano, A. (2005). Personality profiles of cultures: aggregate personality traits. Journal of personality and social psychology, 89(3), 407. 
INTERNATIONAL JOURNAL OF ACADEMIC RESEARCH IN BUSINESS AND SOCIAL SCIENCES

Vol. 10, No. 6, June, 2020, E-ISSN: 2222-6990 @ 2020 HRMARS

Mohd, S., \& Ahmad, J. (2005). Pembinaan modul: Bagaimana membina modul latihan dan modul akademik: Penerbit Universiti Putra Malaysia.

Shariff, M. A. R., Javed, S., \& Md Nadzalan, A. (2019). Relationship of PSYCO-sosial maturity and aggressive behavior among school children. International Journal of Innovative Technology and Exploring Engineering, 8(12), 1075-1079.

Nordin, A. B. (2017). Kurikulum Kearah Penghasilan Kemahiran Berfikiran Kritis, Kreatif dan Inovatif. JuKu: Jurnal Kurikulum \& Pengajaran Asia Pasifik, 1(1), 10-18.

Pallant, J. (2013). SPSS survival manual: McGraw-Hill Education (UK).

Pallant, J., \& Manual, S. S. (2010). A step by step guide to data analysis using SPSS. Berkshire UK: McGraw-Hill Education.

Prihamdani, D. (2016). Pengaruh komunikasi keluarga terhadap penguasaan Bahasa Inggris peserta didik kelas x di SMK Pgri 1 Tambun Kecamatan Tambun Selatan Kabupaten Bekasi. Jurnal Sekolah Dasar, 1(1).

Putnam, R. D. (2000). Bowling alone: The collapse and revival of American community: Simon and schuster.

Rahmat, A., Shahril, M., Salimin, N., Ahmad, M., \& Nadzalan, A. (2017). The assessment of psychomotor domain among reserve officers training team (Palapes). Journal of Fundamental and Applied Sciences, 9(6S), 1389-1397.

Ramlan. (2004). Panduan Pengurusan Kokurikulum di Sekolah. Kuala Lumpur: Banter Sdn. Bhd.

Rani, A., Yusof, M., Kamarulzaman, A., \& Omar, M. R. (2016). Survey on the effects of athletes involvement in the Malaysian Matriculation Co-Curriculum Carnival (KAKOM) on the academic achievement in the Labuan Matriculation College. Jurnal Sains Sukan dan Pendidikan Jasmani, 5(2), 44-52.

Setiadi, H. (2016). Pelaksanaan penilaian pada Kurikulum 2013. Jurnal Penelitian dan Evaluasi Pendidikan, 20(2), 166-178.

Sidik, I. F., Awang, M. M., \& Ahmad, A. R. (2018). Sokongan Persekitaran Sosial di Pelbagai Jenis Sekolah Menengah dalam Meningkatkan Kemahiran Insaniah Pelajar (Social Environmental Support in Various Types of Secondary Schools in Improving Soft Skills Among Students). Jurnal Pendidikan Malaysia (Malaysian Journal of Education), 43(3), 67-76.

Tabachnick, B. G., Fidell, L. S., \& Ullman, J. B. (2007). Using multivariate statistics (Vol. 5): Pearson Boston, MA.

Yaakob, M. F. M., Yunus, J. N., \& Jafar, M. F. (2020). Evaluate the Activities of 1M1S and Co-curriculum in Kedah: Insight from Teachers. Universal Journal of Educational Research, 8(1), 183-190.

Yunus, H. M., \& Ahmad, A. R. (2016). Kemahiran insaniah ke arah pembentukan potensi pelajar. Paper presented at the Proceeding 7th International Seminar on Regional Education.

Yusak, Y. B. M., bin Abdul Rahim, A. I., \& Ramli, A. R. B. (2019). Transformasi Kokurikulum Berkredit Politeknik Malaysia. Journal on Technical and Vocational Education, 4(3), 116-128.

Zakaria, H. B., Nasroddin, S. N. B., \& Hashim, Z. B. (2015). Softskills-kepentingannya dalam memenuhi kebolehpasaran pekerjaan terhadap graduan Politeknik Johor Bahru. THE Journal: Tourism and Hospitality Essentials Journal, 5(2), 921-938. 